enteropathogens on the growth of children in rural Bangladesh. Pediatrics 1984;73:799-80s.

5 Martorell R, Habicht JP, Yarborough C, Lechtig A, Klein RE, Western KA. Acute morbidity and physical growth in rural Guatemalan children. $A m \mathcal{f}$ Dis Child 1975;129:1296-301.

6 Black RE, Merson MH, Taylor PR, et al. Glucose vs sucrose in oral rehydration solutions for infants and young children with rotavinusassociated diarrhea. Pediatrics 1981;67:79-83.

7 Kielmañn AA, McCord C. Weight-for-age as an index of risk of death in children. Lancet 1978; $1: 1247-50$

8 Chen LC, Chowdhury AKMA, Huffman SA. Anthropometric assessment.of energy-protein malnutrition and subsequent risk of mortality among preschool aged children. Am $\mathcal{F}$ Clin Nutr 1980;33:1836-45.

9 Trowbridge FL, Newton LH. Seasonal changes in malnutrition and diarrheal disease among preschool children in El Salvador. Am $f$ Trop Med Hyg 1979;28:135-41

10 Trowbridge FL, Newton LH, Campbell CC. Nutritional status and the severity of diarrhoea. Lancet $1981 ; \mathrm{i}: 1375$.

11 Gordon JE, Guzman MA, Ascoli W, Scrimshaw NS. Acute diarrheal diseas in less developed countries. 2. Patterns of epidemiological behavior in rural Guatemalan villages. Bull WHO 1964;31:9-20.

12 Tomkins A. Nutritional status and severity of diarrhoea among preschool children in rural Nigeria. Lancet $1981 ; \mathrm{i}: 860-2$.

13 Black RE, Brown $\mathrm{KH}$, Becker S. Malnutrition is a determining factor in diarrheal duration, but not incidence, among young children in a longitudinal study in rural Bangladesh 1-3. Am $\mathcal{F}$ Clin Nutr 1984;39:87-94.

14 Gomez F, Galvan RR, Cravioto J, Frenk S. Malnutrition in infancy and childhood, with special reference to kwashiorkor. In: Levine SZ, ed. childhood, with special reference to kwashiorkor. In: Levine SZ, ed.

15 Nie NH, Hull CH, Jenkins JG, Steinbronner K, Bent DH. Statistical package for the social sciences. New York: McGraw Hill, 1975.

16 Breslow NE, Day NE. Statistical methods in cancer research. Vol 1 . The analysis Breslow NE, Day NE. Statistical methods in cancer research. Vol 1. The analysis
of case-control studies. Lyons: International Association for Research on Cancer, 1980:142-3. (Scientific publication No 32.)

17 Rothman KJ, Boice JD. Epidemiologic analysis with a programmable calculator. Boston: Epidemiology Resources, 1982:5-7.
18 Miettinen OS. Estimability and estimation in case-referent studies. Am $\mathcal{J}$ Epidemiol 1976;103:226-35.

19 Schlesselman J. Case control studies. Design, conduct, analysis. New York: Oxford University Press, 1982:227-90.

20 Munson D, Franco D, Arbeter A, Velez H, Vitale JJ. Serum levels of immunoglobulins, cell-mediated immunity and phagocytosis in proteincalories malnutrition. Am f Clin Nutr 1974;27:625-8.

21 Schlesinger D, Stekel A. Impaired cellular immunity in marasmic infants. Am f Clin Nutr 1974;27:615-20.

22 Purtilo DT, Riggs RS, Evans R, Neafie RC. Humoral immunity of parasitized, malnourished children. Am $\mathcal{Y}$ Trop Med Hyg 1976;25:229-32

23 Koster F, Gaffar A, Jackson TM. Recovery of cellular immune competence during treatment of protein-calorie malnutrition. Am $\mathcal{F}$ Clin Nutr 1981;34 $887-91$.

24 Chandra RK. Reduced secretory antibody response to live attenuated measles and poliovirus vaccine in malnourished children. Br Med $\mathcal{F} 1975$;ii:583-5.

25 Sirisinha S, Suskind R, Edelman R, Asvapaka C, Olson RE. Secretory an serum IgA in children with protein-calorie malnutrition. Pediatrics 1975; 55:166-70.

26 Green F, Heyworth B. Immunoglobulin-containing cells in jejunal mucosa of children with protein energy malnutrition and gastroenteritis. Arch Dis Child 1980;55:380-3.

27 Kielmann AA, Uberoi IS, Chandra RK, et al. The effect of nutritional status on immune capacity and immune responses in preschool children in a rural community in India. Bull WHO 1976;54:477-83.

28 Brunser O, Reid A, Monckeberg F, Maccioni A, Contreras I. Jejunal mucosa in infant malnutrition. Am $\mathcal{F}$ Clin Nutr 1968;21:976-83.

29 Hisschhorn N, Molla A, Molla AM. Reversible jejunal disaccharidase deficiency in cholera and other acute diarrheal diseases. Johns Hopkins Medical foumal 1969;125:291-300.

30 Coello-Ramirez P, Lifshitz F, Zuniga V. Enteric microflora and carbohydrate intolerance in infants with diarrhea. Pediatrics 1972;49:233-42.

31 Gribbin M, Walker-Smith J, Wood C. Delayed recovery following acute gastroenteritis. Acta Paediatrica Belgica 1976;29:167-76.

(Accepted 17 February 1989)

\title{
Smoking and leanness: evidence for change in Finland
}

\author{
Bernard Marti, Jaakko Tuomilehto, Heikki J Korhonen, Leena Kartovaara, Erkki Vartiainen, \\ Pirjo Pietinen, Pekka Puska
}

\begin{abstract}
Many studies have shown smokers to weigh less than non-smokers, which is plausible given the metabolic effects of cigarette smoke. The interrelation between smoking and relative body weight and its change over time were analysed by using data from Finnish population based surveys from 1982 and 1987. Among both men and women the inverse association between smoking and body mass index was clearly weakened between 1982 and 1987 . In 1987 among men aged 25-44 smoking was positively related to body mass index. Moreover, the relation between smoking and waist to hip girth ratio was positive in both sexes at all ages. Years of smoking was nevertheless confirmed as a significant inverse predictor of relative weight. A cluster of unfavourable health habits, including high consumption of alcohol and saturated fats, especially emerged among younger smokers. This may have been due to different selection of smokers in Finland, where smoking increasingly seems to be a form of deviant or risk taking behaviour.
\end{abstract}

It is concluded that at a population level the metabolic effects of smoking seem to be increasingly overridden by several other unfavourable health behaviours of smokers.

\section{Introduction}

Numerous epidemiological studies have compared the body weights of smokers and non-smokers, and nearly all have found that smokers as a group weigh less than people who have never smoked. ${ }^{1-11}$ Among men the inverse association between smoking and body weight is strongest in older smokers and weakest in younger smokers, which may be due to the duration of smoking. ${ }^{347}$ For example, metabolic studies have shown that smokers have an increased resting energy expenditure. ${ }^{12}$ Behavioural, environmental, and cognitive factors, however, are also active determinants of diet, exercise, and body weight. ${ }^{4}$ Indeed, smoking has shown a $U$ shaped relation with relative weight in several studies, smokers of 5-20 cigarettes a day being the leanest. ${ }^{2357813}$

Though paradoxical given the metabolic effects of smoking, possibly heavier smokers may weigh more because they have other unhealthy habits such as heavy drinking and little exercise. ${ }^{14}$ 15

This paper examines the association between smoking and body mass index among the Finnish population in 1982 and 1987. The study used population based data collected as part of the World Health Organisation's multinational project of monitoring trends and determinants in cardiovascular diseases (MONICA). ${ }^{16}$

\section{Subjects and methods}

In 1982 and 1987 cross sectional surveys of risk factors were carried out in four areas in Finland. ${ }^{16}$ Independent random samples were drawn from these four populations covering the age range 25-64 years. Response rates in the surveys were $80-94 \% .^{16} 17$ This analysis is based on data from 4508 men and 4648 women in 1982 and 2913 men and 3212 women in 1987. The surveys included a self administered questionnaire checked by an interviewer and physical measurements. Weight, height, and girth of waist and hips were measured in light clothing by trained personnel. The body mass index (weight $(\mathrm{kg})$ divided by height (m) squared) was used as a measure of relative body weight.

Information on smoking was obtained by seven standardised questions in the questionnaire. Those subjects who reported that they had smoked regularly for at least a year and at least once a day on average 
during the past month were classified as current smokers. All others were classified as current nonsmokers. The participants reported the number of years of regular smoking and current smokers the number of cigarettes, pipefuls, or cigars smoked daily. In 1987 only $56(1.9 \%)$ of the men and $3(0 \cdot 1 \%)$ of the women reported smoking pipe or cigars, and these forms of smoking accounted for less than $3 \%$ of the overall number of episodes of daily smoking in men and practically none in women.

Alcohol consumption was assessed by questions on the amount of beer, mild alcoholic beverages, strong alcoholic beverages, and wine consumed in the previous seven days. Alcohol consumption in $\mathrm{g} /$ week was estimated by applying the average alcoholic content and sizes of bottles or portions in Finland. ${ }^{18} \mathrm{An}$ overall index of saturated fat intake was calculated on the basis of answers to questions related to consumption of milk fat and amount and type of fat spread used on bread. ${ }^{19}$ Leisure time physical activity was assessed on a four point scale by means of a multiple choice question characterising the amount and type of usual exercise. $^{20}$

Associations of smoking state with the body mass index and their change over time (period effect) were analysed for men and women separately by two way analysis of variance, age being entered as a covariate. Mean values of body mass index among subgroups stratified by different numbers of years of smoking were adjusted for age and the number of cigarettes smoked daily with general linear models, and determinants of body mass index among smokers were also analysed by multiple least squares linear regression. Standard statistical software packages were used for analyses. ${ }^{2122}$

TABLE I-Age adjusted means and analysis of variance of body mass index $\left(\mathrm{kg} / \mathrm{m}^{2}\right)$ among Finnish men and women stratified by smoking state and period (1982 and 1987)

\begin{tabular}{|c|c|c|c|c|}
\hline & \multicolumn{2}{|c|}{1982} & \multicolumn{2}{|c|}{1987} \\
\hline & $\begin{array}{l}\text { Body mass } \\
\text { index }\end{array}$ & No studied & $\begin{array}{l}\text { Body mass } \\
\text { index }\end{array}$ & No studied \\
\hline \multicolumn{5}{|l|}{ Men: } \\
\hline Non-smokers & $26 \cdot 65$ & 2779 & $26 \cdot 97$ & 1911 \\
\hline Current smokers & $25 \cdot 82$ & 1729 & $26 \cdot 45$ & 1002 \\
\hline Total & $26 \cdot 32$ & 4508 & $26 \cdot 79$ & 2913 \\
\hline \multirow{2}{*}{\multicolumn{5}{|c|}{$\begin{array}{l}\text { Difference between } \\
\text { non-smokers and } \\
\text { smokers }\end{array}$}} \\
\hline & & & & \\
\hline \multicolumn{5}{|l|}{ Women: } \\
\hline Non-smokers & $26 \cdot 19$ & 3852 & $26 \cdot 51$ & 2691 \\
\hline Current smokers & $24 \cdot 43$ & 796 & $25 \cdot 09$ & 521 \\
\hline Total & $25 \cdot 88$ & 4648 & $26 \cdot 27$ & 3212 \\
\hline \multicolumn{5}{|l|}{$\begin{array}{l}\text { Difference between } \\
\text { non-smokers and } \\
\text { smokers }\end{array}$} \\
\hline
\end{tabular}

Main effects: period (subjects heavier in 1987 than in 1982), men $p<0.001$ women $\mathrm{p}<0.001$; smoking state (non-smokers heavier than smokers), men $\mathrm{p}<0.001$, women $<0.001$.

Two-way interaction: period by smoking state (five year increase in body mass index greater in smokers than non-smokers), men $p=0.036$, women $\mathrm{p}=0 \cdot 118$.
TABLE III-Mean values of body mass index $\left(\mathrm{kg} / \mathrm{m}^{2}\right)$ adjusted for age and number of cigarettes smoked daily stratified by duration of smoking history among 990 male current smokers in 1987 *

\begin{tabular}{|c|c|c|c|c|c|}
\hline & \multicolumn{5}{|c|}{ Years of smoking } \\
\hline & $\begin{array}{c}1-10 \\
(n=200)\end{array}$ & $\begin{array}{c}11-20 \\
(\mathbf{n}=372)\end{array}$ & $\begin{array}{c}21-30 \\
(n=253)\end{array}$ & $\begin{array}{c}31-40 \\
(n=126)\end{array}$ & $\begin{array}{c}\geqslant 41 \\
(\mathrm{n}=39)\end{array}$ \\
\hline $\begin{array}{l}\text { Body mass } \\
\text { index (SE) }\end{array}$ & $\begin{array}{l}26.95 \\
(0.30)\end{array}$ & $\begin{array}{l}26 \cdot 90 \\
(0.22)\end{array}$ & $\begin{array}{l}26 \cdot 19 \\
(0 \cdot 26)\end{array}$ & $\begin{array}{l}25.63 \\
(0.37)\end{array}$ & $\begin{array}{l}24.06 \\
(0.69)\end{array}$ \\
\hline
\end{tabular}

${ }^{\star}$ Remaining 12 male current smokers in 1987 excluded from analysis because of lack of data.

\section{Results}

Table I presents the mean values of body mass index in men and women in 1982 and 1987 stratified by smoking state. Overall there was a significant increase in weight in both sexes from 1982 to 1987 . The increase among men was significantly greater in smokers than non-smokers ( $p=0.036$ for interaction), and a similar trend was observed among women.

Age emerged as an important modifying factor of the association between smoking and weight (table II); in both sexes the inverse relation tended to be stronger in older (age 45-64) than younger subjects (25-44). The correlations were of low order, indicating that smoking was not a main determinant of relative weight. From 1982 to 1987, however, all correlation coefficients showed a remarkably consistent shift (by 0.03 to 0.07 ) in the positive direction. Thus in 1987 a significant positive association between smoking and weight was observed in all younger men, and in the older men the inverse association substantially decreased from 1982 to 1987 . In addition, in 1987 both younger men and women showed a positive association between smoking and the waist to hip girth ratio.

To elucidate the reasons for the apparent reduction in weight difference between smokers and nonsmokers between the two survey years determinants of body weight among current smokers were first analysed cross sectionally. In the 1987 data age was a strong predictor of body weight among the younger smokers, but among the older smokers duration of smoking was the strongest. The number of cigarettes smoked a day was a significant positive predictor of body weight in younger but not older men (data not shown). When the analysis was repeated for the 1982 data the findings were practically identical. This showed that among the smokers smoking related predictors of body weight had not changed.

To estimate the importance of years of smoking as a predictor of body weight in men mean values of body mass index adjusted for age and number of cigarettes smoked daily were computed for men with histories of $1-10,11-20,21-30,31-40$, and $\geqslant 41$ years of smoking (table III). There was a consistent inverse gradient between years of smoking and relative weight that was especially pronounced after more than 20 years of smoking.

Among men smokers drank more alcohol, ate more saturated fats, exercised less, were less well educated, and had higher resting heart rates than non-smokers

TABLE II - Linear correlation coefficients of smoking with body mass index ( $\left.\mathrm{kg} / \mathrm{m}^{2}\right)$ among Finnish men and women aged 25-64 in 1982 and 1987 and linear correlation coefficients of smoking with waist to hip girth ratio in subjects of same age ranges in 1987

\begin{tabular}{|c|c|c|c|c|c|c|c|}
\hline \multirow{2}{*}{. } & & \multicolumn{3}{|c|}{1982} & \multicolumn{3}{|c|}{1987} \\
\hline & & Age 25-44 & Age 45-64 & Total & Age $25-44$ & Age 45-64 & Total \\
\hline $\begin{array}{l}\text { Smoking }{ }^{\star} \text { with body } \\
\text { mass index }\end{array}$ & $\left\{\begin{array}{l}\text { Men } \\
\text { Women }\end{array}\right.$ & $\begin{array}{r}0.03(2300) \\
-0.03(2227)\end{array}$ & $\begin{array}{l}-0.13(2208) \\
-0.12(2421)\end{array}$ & $\begin{array}{l}-0.06(4508) \\
-0.15(4648)\end{array}$ & $\begin{array}{l}0.06(1364) \\
0.00(1528)\end{array}$ & $\begin{array}{l}-0.06(1549) \\
-0.08(1684)\end{array}$ & $\begin{array}{l}-0.02(2913) \\
-0.11(3212)\end{array}$ \\
\hline $\begin{array}{l}\text { Smoking }{ }^{\star} \text { with waist to hip } \\
\text { girth ratio }\end{array}$ & $\left\{\begin{array}{l}\text { Men } \\
\text { Women }\end{array}\right.$ & & & & $\begin{array}{l}0.11(1364) \\
0.08(1528)\end{array}$ & $\begin{array}{l}0.04(1549) \\
0.04(1684)\end{array}$ & $\begin{array}{l}0.05(2913) \\
0.01(3212)\end{array}$ \\
\hline
\end{tabular}

* Seven point scale: never smoked $=1$; ex-smoker for $\geqslant 6$ months $=2$; ex-smoker for $<6$ months $=3$; irregular smoker $=4$; current smoker of $1-14$ cigarettes a day $=5$; current smoker of $15-24$ cigarettes a day $=6$; current smoker of $\geqslant 25$ cigarettes a day $=7$. 


\begin{tabular}{|c|c|c|c|c|c|c|}
\hline & \multicolumn{3}{|c|}{1982} & \multicolumn{3}{|c|}{1987} \\
\hline & $\begin{array}{c}\text { Non-smokers } \\
(n=2779 ; \\
61 \cdot 6 \%)\end{array}$ & $\begin{array}{c}\text { Smokers } \\
(\mathrm{n}=1729 ; \\
38 \cdot 4 \%)\end{array}$ & $\begin{array}{c}\text { All } \\
(\mathrm{n}=4508 \\
100 \cdot 0 \%)\end{array}$ & $\begin{array}{c}\text { Non-smokers } \\
(\mathrm{n}=1911 ; \\
65 \cdot 6 \%)\end{array}$ & $\begin{array}{c}\text { Smokers } \\
(\mathrm{n}=1002 ; \\
34 \cdot 4 \%)\end{array}$ & $\begin{array}{c}\text { All } \\
(n=2913 \\
100 \cdot 0 \%)\end{array}$ \\
\hline $\begin{array}{l}\text { Alcohol consumption }{ }^{\star}(\mathrm{g} / \text { week }) \\
\text { Saturated fat intake }(\mathrm{g} / \mathrm{day}) \\
\text { Leisure time exercisef } \\
\text { Years of education } \\
\text { Resting heart rate (beats/min) } \\
\text { Age (years) } \\
\text { Cigarettes smoked daily }\end{array}$ & $\begin{array}{l}46 \cdot 0(76 \cdot 0) \\
28 \cdot 2(21 \cdot 3) \\
2 \cdot 01(0 \cdot 77) \\
9 \cdot 1(3 \cdot 8) \\
69 \cdot 0(12 \cdot 5) \\
45 \cdot 2(11 \cdot 0) \\
\end{array}$ & $\begin{array}{l}95 \cdot 3(141 \cdot 5) \\
32 \cdot 8(23 \cdot 1) \\
1 \cdot 75(0 \cdot 70) \\
8 \cdot 8(3 \cdot 2) \\
74 \cdot 8(12 \cdot 9) \\
42 \cdot 9(11 \cdot 2) \\
18 \cdot 2(9 \cdot 3)\end{array}$ & $\begin{array}{l}65 \cdot 3(109 \cdot 2) \\
30 \cdot 0(22 \cdot 2) \\
1 \cdot 91(0 \cdot 75) \\
9 \cdot 0(3 \cdot 6) \\
71 \cdot 2(12 \cdot 9) \\
44 \cdot 3(11 \cdot 1)\end{array}$ & $\begin{array}{c}45 \cdot 5(71 \cdot 1) \\
24 \cdot 0(19 \cdot 8) \\
2 \cdot 00(0 \cdot 74) \\
9 \cdot 8(3 \cdot 8) \\
70 \cdot 0(12 \cdot 4) \\
46 \cdot 1(11 \cdot 3) \\
\quad-\end{array}$ & $\begin{array}{l}95 \cdot 8(150 \cdot 1) \\
30 \cdot 9(23 \cdot 2) \\
1 \cdot 78(0 \cdot 70) \\
9 \cdot 4(3 \cdot 4) \\
75 \cdot 9(13 \cdot 1) \\
43 \cdot 3(10 \cdot 9) \\
18 \cdot 3(9 \cdot 8)\end{array}$ & $\begin{array}{l}63 \cdot 4(108) \\
26 \cdot 4(21 \cdot 3) \\
1 \cdot 93(0 \cdot 73) \\
9 \cdot 7(3 \cdot 7) \\
72 \cdot 0(13 \cdot 0) \\
45 \cdot 1(11 \cdot 3)\end{array}$ \\
\hline
\end{tabular}

‡Self reported alcohol consumption during week preceding surveys.

†Saturated fat from milk and fat used on bread only (see text for results of analysis of variance).

$\ddagger$ Four point scale from sedentary to training for competitive endurance sports.

(table IV). With the exception of consumption of saturated fats these differences remained remarkably stable between 1982 and 1987. With respect to saturated fat consumption, however, the downward trend was significantly steeper in non-smokers $(-4.2 \mathrm{~g} /$ day $)$ than smokers $(-1.9 \mathrm{~g} /$ day $)(\mathrm{p}=0.025$ for age adjusted interaction for period by smoking state). Among women smokers had a lower mean age than non-smokers. Saturated fat intake also decreased in women between 1982 and 1987 -in non-smokers by $3.1 \mathrm{~g} /$ day but in smokers by only $1.3 \mathrm{~g} /$ day $(\mathrm{p}=0.021$ for age adjusted interaction for period by smoking state).

A further analysis of variance of body mass index in current male smokers in 1987 examined the interaction effect of alcohol consumption and age. Among the 25-44 year olds the highest average body mass index was found in those who were both heavy smokers and heavy drinkers, whereas in the older age group (45-64) men with high cigarette and alcohol consumption had the lowest body mass index. Owing to the comparatively small numbers of current smokers who reported some alcohol consumption during the week before the survey the three way interaction term failed to reach significance $(p=0 \cdot 10)$. The finding nevertheless illustrated the opposed character of the smokingalcohol-weight interrelation between younger men (synergistic) and older men (antagonistic) and indicated that the clustering of unhealthy habits tended to be more pronounced in younger than older middle aged men. Similar associations with body weight, alcohol consumption, and age were not seen in women smokers.

\section{Discussion}

Years of smoking have been shown to be the main determinant of lung cancer. Recently years of smoking has been recognised as the most informative measure of smoking for the risk of cardiovascular disease. ${ }^{23}$ It is also a predictor of body weight, ${ }^{7}$ and our cross sectional data accord with other observations of an inverse association between the duration of smoking and relative weight for men. Metabolic studies have shown an increased resting energy expenditure in smokers, ${ }^{12}$ so it is not surprising that the cumulative negative effect of smoking on body weight should be most clearly seen after several years of smoking. An increased metabolic rate among smokers might also explain why smokers weigh less than non-smokers despite their sometimes higher energy intake and often lower levels of leisure activity. ${ }^{3424}$ On the other hand, the daily amount of smoking was a positive rather than negative predictor of body weight in younger smokers. Similar findings have been reported from The Netherlands. ${ }^{5}$

Our main finding was that the usually observed inverse association of smoking with body weight ${ }^{1-11}$ disappeared in Finnish men and became substantially attenuated in Finnish women during 1982-7. More- over, in as short a time as five years a substantial increase in weight had occurred both in smokers and in non-smokers. Interestingly, recently published figures from the United States also show that in two large population based surveys smokers were leaner than non-smokers in 1976-80 but no longer so in 1981-3. ${ }^{10}$

We have little doubt that our observation was real. Weight and height of all subjects were measured by trained personnel under standardised conditions. Self reported smoking habits have been validated by measurement of serum thiocyanate concentration and shown to be reliable. ${ }^{17}$ Alcohol consumption during the week before the survey was validated by measurement of serum $\gamma$-glutamyltransferase activity, ${ }^{18}$ and the appropriateness of the saturated fat intake variable, based on milk, butter, and margarine consumption, was tested with three day food consumption records. ${ }^{25}$

What might be the reasons for a diminishing difference in body weight between smokers and nonsmokers in Finland? Other workers have also noted an intriguing modifying effect of age on the association between smoking history and body weight in cross sectional analyses. ${ }^{37}$ In a large representative sample of men and women from the United States current smokers aged up to 34 and with a history of smoking for 1-20 years were not leaner than age matched nonsmokers, whereas smokers aged 50 or over and with a history of smoking for less than 11 years were significantly leaner than non-smokers. ${ }^{7}$ Even though biological effects of cigarette smoke on humans require a long incubation period, the observation that younger smokers show a smaller effect of an equal number of years of smoking on body mass index than older smokers suggests that factors other than smoking are responsible, possibly related to health habits.

Individual health behaviour with an increased clustering of unfavourable health habits especially among younger men might be the most likely explanation for our results. From our data male and female Finnish smokers showed a significant departure from the population wide trend towards a lower saturated fat intake from 1982 to 1987 . This suggests that smokers may have been more resistant to adopting healthier dietary habits than non-smokers, which may reflect current smokers' lack of interest in health promotion in general. This seemed to be particularly true for the younger male smokers, as the combination of high alcohol and high cigarette consumption was associated with higher relative weight in younger men but not in older men or in women. This agrees with an observation from the United States that alcohol consumption tended to mitigate the inverse smoking-body mass index relation in men but not in women. ${ }^{10}$ Secondly, smoking was significantly and positively related to the waist to hip girth ratio in younger men. ${ }^{26}$ Interestingly the waist to hip girth ratio has been suggested as a better predictor of coronary risk than body mass index. ${ }^{6}$ Waist to hip girth ratio reflects the distribution of body fat and may be more closely related to health habits and lifestyle than the body mass 
index, which is also modified by differences in body build and muscularity. ${ }^{27}$ In general our results accord with observations from the United States of a clustering of negative health habits among smokers, which may have become more pronounced in recent years. ${ }^{8}$

We can only speculate why the characteristics of smokers in Finland seem to be changing. In the past smoking was considered to be a "normal" habit; but with the Finnish antismoking legislation from 1977, increased antismoking education, and changing public attitudes smoking is being regarded more as a deviant behaviour. Thus today smokers may be personalities more prone to risk taking and unhealthy behaviours than earlier. It may be hypothesised that the hard core of current smokers, who hitherto have resisted antismoking campaigns, consist of an increasing selection of people with unfavourable health behaviour. In another Finnish study ${ }^{28}$ persistence in smoking was associated with greater use of alcohol and coffee, possibly due to a common pathophysiology of dependence. ${ }^{29}$ On the other hand, the average number of cigarettes smoked daily by current smokers did not increase from 1982 to 1987 as one would expect for the hypothesis of an increasing cluster of negative health habits.

In conclusion our population based data from large samples of middle aged Finnish men and women suggest that the metabolic effects of smoking are apparently increasingly overridden by the present behavioural characteristics of smokers such as high alcohol and saturated fat consumption and little exercise. The earlier generally accepted notion that smokers weigh less than non-smokers ${ }^{11}$ may thus soon turn out to be anachronistic. It also seems plain that antismoking health education aimed at young and middle aged men should place more emphasis on correcting an unhealthy lifestyle as a whole.

BM was supported by grant No 3.763-0.87 from the Swiss National Science Foundation.

1 Gordon T, Kannel WB, Dawber TR, McGee D. Changes associated with quitting cigarette smoking: the Framingham study. Am Heart $f$ 1975;90: 322-8.

2 Noppa $\mathrm{H}$, Bengtsson C. Obesity in relation to smoking: a population study of women in Göteborg, Sweden. Prev Med 1980;9:534-43.

3 Jacobs DR, Gothenborg S. Smoking and weight: the Minnesota Lipid Research Clinic. Am f Public Health 1981;71:391-6.

4 Wack JT, Rodin J. Smoking and its effects on body weight and the systems of caloric regulation. Am f Clin Nutr 1982;35:366-80.

5 Baecke JA, Burema J, Frijters JE, Hautvast JG, Wiel-Wetzels WA. Obesity in young Dutch adults (II): daily life-style and body mass index. Int $\mathcal{f}$ Obes $1983 ; 7: 13-24$

6 Larsson B, Svärdsudd K, Welin L, Wilhelmsen L, Björntorp P, Tibblin G. Abdominal adipose tissue distribution, obesity, and risk of cardiovascular disease and death: 13 year follow-up of participants in the study of men born in 1913. Br Med F 1984;288:1401-4.

7 Albanes D, Jones Y, Micozzi MS, Mattson M. Associations between smoking and body weight in the US population: analysis of NHANES II. Am $\mathcal{Y}$ Public Health 1987;77:439-44.

8 National Center for Health Statistics, Schoenborn CA, Benson V. Relationships between smoking and other unhealthy habits: United States, 1985. Hyattsville, Md: United States Department of Health and Human Services, 1988. (Advance Data from Vital and Health Statistics, No 154.)

9 Lund-Larsen PG, Tretli S. Changes in smoking habits and body weight after a three-year period - the cardiovascular disease study in Finmark. $f$ Chronic
a Dis $1982 ; 35: 773-80$

10 Williamson DF, Forman MR, Binkin NJ, Gentry EM, Remington PL, Trowbridge FL. Alcohol and body weight in United States adults. Am f Public Health 1987;77:1324-30.

11 Kromhout $D$, Saris WH, Horst $C H$. Energy intake, energy expenditure, and smoking in relation to body fatness: the Zutphen study. Am $\mathcal{Y}$ Clin Nutr 1988;47:668-74

12 Hofstetter A, Schutz Y, Jequier E, Wahren J. Increased 24-hour energy expenditure in cigarette smokers. $N$ Engl f Med 1986;314:79-82.

3 Killen JD, Fortmann SP, Telch MJ, Newman B. Are heavy smokers different from light smokers? JAMA 1988;260:1581-5.

14 Marti B, Salonen JT, Tuomilehto J, Puska P. 10-Year trends in physical activity in the eastern Finnish adult population: relationship to socioeconomic and lifestyle characteristics. Acta Med Scand 1988;224:195-203.

15 Salonen JT, Puska P, Kottke TE, Heinonen OP. Coronary risk factor clustering patterns in eastern Finland. Int $\mathcal{F}$ Epidemiol 1981;10:203-10.

16 Puska P, Salonen JT, Nissinen A, et al. Change in risk factors for coronary Puska P, Salonen JT, Nissinen A, et al. Change in risk factors for coronary
heart disease during 10 years of a community programme (North Karelia project). Br Med f 1983;287:1840-4.

17 Puska P, Tuomilehto J, Salonen JT, et al. The North Karelia project: a comprehensive community programme for control of cardiovascular diseases in North Karelia, Finland 1972-1977. Copenhagen: WHO/EURO, 1981.

18 Salonen JT, Happonen P, Salonen R, et al. Interdependence of associations of physical activity, smoking, and alcohol and coffee consumption with serum high-density lipoprotein and non-high-density lipoprotein cholesterol-a population study in eastern Finland. Prev Med 1987;16:647-58.

19 Pietinen P, Nissinen A, Vartiainen E, et al. Dietary changes in the North Karelia project (1972-1982). Prev Med 1988;17:183-93.

20 Tuomilehto J, Marti B, Salonen JT, Virtala E, Lahti T, Puska P. Leisuretime physical activity is inversely related to risk factors for coronary heart time physical activity is inversely related to risk factors for coro

21 SPSS. Statistical package for the social sciences. SPSSX advanced statistics guide. Chicago, Illinois: SPSS, 1985.

22 SAS Institute. Statistical analyses system. SAS user's guide: statistics. 5th ed. Cary, North Carolina: SAS Institute, 1985.

23 Cook DG, Shaper AG, Pocock SJ, Kussick SJ. Giving up smoking and the risk of heart attacks: a report from the British regional heart study. Lance 1986;ii:1376-9.

24 Stamford BA, Matter S, Fell RD, Sady S, Cresanta M, Papanek P. Cigarette smoking, exercise and high density lipoprotein cholesterol. Atherosclerosis 1984;52:73-83.

25 Pietinen P, Uusitalo U, Vartiainen E, Tuomilehto J. Dietary survey of the FINMONICA project in 1982. Acta Med Scand 1988; suppl 728: 169-77.

26 Shimokata H, Muller DC, Andres R. Studies in the distribution of body fat: effects of cigarette smoking. FAMA 1989;261:1169-73.

27 Vague J. La differentiation sexuelle humaine. Ses incidences en pathologie. Paris: Masson Editeur, 1953:386-96.

28 Kaprio J, Koskenvuo M. A prospective study of psychological and socioeconomic characteristics, health behavior and morbidity in cigarette economic characteristics, health behavior and morbidity in cigarette foumal of Clinical Epidemiology 1988;41:139-50.

29 Istvan J, Matarazzo JD. Tobacco, alcohol, and caffeine use: a review of their Istvan J, Matarazzo JD. Tobacco, alcohol, and cal
interrelationships. Psychol Bull 1984;95:301-26.

(Accepted 8 March 1989)

\section{Intralesional tumour necrosis factor combined with interferon gamma in metastatic melanoma}

\section{S Retsas, M Leslie, D Bottomley}

Medical Oncology Unit, Westminster Hospital, London SW1P 2AP

S Retsas, MD, consultant medical oncologist

$M$ Leslie, MRCP, registrar in oncology

D Bottomley, MRCP, senior house officer

Correspondence to:

Dr Retsas.

BrMed f 1989;298: 1290-1
Recombinant tumour necrosis factor $\alpha$ and interferon gamma are cytokines that show synergistic antitumour activity in vitro against clonogenic human tumour cells. ${ }^{12}$ Remission rates of up to $40 \%$ after direct injection of recombinant tumour necrosis factor $\alpha$ into the tumour have been reported. ${ }^{2}$ We looked at the therapeutic potential of these two cytokines used together in seven patients with advanced metastatic malignant melanoma.

\section{Patients, methods, and results}

The study was approved by the hospital ethical committee. Three women and four men with a median age of 44 years (range 28 to 57) took part. All patients had progressive disease in more than two organ sites, which was distributed as follows: skin (seven patients), lymph nodes (three), lung (three), bone (two), and brain (one). They had all previously been treated with chemotherapy, with a median of five drugs (range four to 11 ), and three had also received interferon alfa. Cerebral and cutaneous metastases in one woman had previously responded to chemotherapy with the DJV3 combination (vindesine, dacarbazine, carboplatin, vinblastine, and vincristine), and another patient had had a prolonged remission with interferon alfa, as already reported. ${ }^{34}$

The planned treatment regimen was recombinant interferon gamma $100 \mu \mathrm{g} / \mathrm{m}^{2}$ body surface area intramuscularly thrice weekly, followed by injection of recombinant tumour necrosis factor $\alpha$ once weekly into the lesion at an initial dose of $5 \mu \mathrm{g} / \mathrm{m}^{2}$ and increasing to a maximum of $150 \mu \mathrm{g} / \mathrm{m}^{2}$ if tolerance permitted. Selected subcutaneous lesions were injected, repeatedly when possible, except in one patient who lacked a suitable lesion and was injected subcutaneously. 